\title{
Primary Thyroid Lymphoma: External Beam Radiation Therapy Induced Thyroiditis Mimics Residual Disease on Serial I8F-FDG PET/CT Imaging
}

\author{
Primer Tiroid Lenfoması: Eksternal Işın Radyasyon Tedavisi ile Indüklenmiş Tiroidit I8F-FDG \\ PET/BT Rezidü Hastalığı Taklit Eder
}

(D) William Makis', (D) Anthony Ciarallo2, (D) Stephan Probst3

'Cross Cancer Institute, Department of Diagnostic Imaging, Edmonton, Canada

2McGill University Health Centre, Department of Nuclear Medicine, Montreal, Canada

3)ewish General Hospital, Department of Nuclear Medicine, Montreal, Canada

\begin{abstract}
A 67-year-old female patient with no prior history of benign thyroid disease was diagnosed with primary thyroid lymphoma and was staged with 18F-fluoro-2-deoxy-D-glucose (18F-FDG) positron emission tomography/computed tomography (PET/ $\mathrm{CT}$ ). She was treated with chemotherapy and external beam radiation therapy, and a follow-up PET/CT showed significant reduction in the size of the thyroid lymphoma with persistent intense 18F-FDG uptake, which was interpreted as partial response to therapy. However, two subsequent PET/CT studies showed no change in the persistent intense 18F-FDG uptake in the thyroid and a biopsy confirmed the presence of thyroiditis with no evidence of residual lymphoma. Follow-up PET/CTs performed over the subsequent three years showed stable intensely 18F-FDG avid thyroiditis with no evidence of lymphoma recurrence. We present the imaging characteristics of a long term radiation treatment induced thyroiditis mimicking ${ }^{18 F-F D G}$ avid residual disease on PET/CT.
\end{abstract}

Keywords: Thyroid lymphoma, thyroiditis, pitfall, artifact, 18F-FDG, PET

\begin{abstract}
Öz
İyi huylu tiroid hastalığı anamnezi olmayan 67 yaşında bir kadına primer tiroid lenfoması tanısı konularak 18F-florodeoksiglukoz (18F-FDG) pozitron emisyon tomografisi/bilgisayarlı tomografi (PET/BT) ile evreleme yapılmıştı. Kemoterapi ve eksternal radyasyon tedavisi uygulanması sonrası takip PET/BT'de tiroid lenfomasında anlamlı çap küçülmesi saptanarak, devam eden yoğun 18F-FDG tutulumu tedaviye kısmi cevap olarak değerlendirilmişti. Ne var ki, takip eden iki PET/BT'de tiroiddeki persistan yoğun 18F-FDG tutulumu gerilememiş ve biyopside rezidü lenfoma olmaksızın tiroidit bulunmuştu. Takip eden üç yıl boyunca çekilen PET/BT'lerde stabil yoğun 18F-FDG tutan tiroidit, lenfoma nüksü olmaksızın devam etmiştir. Burada PET/BT'de 18F-FDG tutan rezidüel hastalığı taklit eden uzun dönemli radyasyona bağlı tiroidite bağlı görüntüleme özelliklerini sunuyoruz.

Anahtar kelimeler: Tiroid lenfoma, tiroidit, tuzak, artefakt, 18F-FDG, PET
\end{abstract}

Address for Correspondence: William Makis MD, Cross Cancer Institute, Department of Diagnostic Imaging, Edmonton, Canada Phone: +90 7804328760 E-mail: makisw79@yahoo.com ORCID ID: orcid.org/0000-0003-0241-3426

Received: 31.12.2016 Accepted: 15.10.2017

${ }^{\circ}$ Copyright 2018 by Turkish Society of Nuclear Medicine

Molecular Imaging and Radionuclide Therapy published by Galenos Yayınevi. 


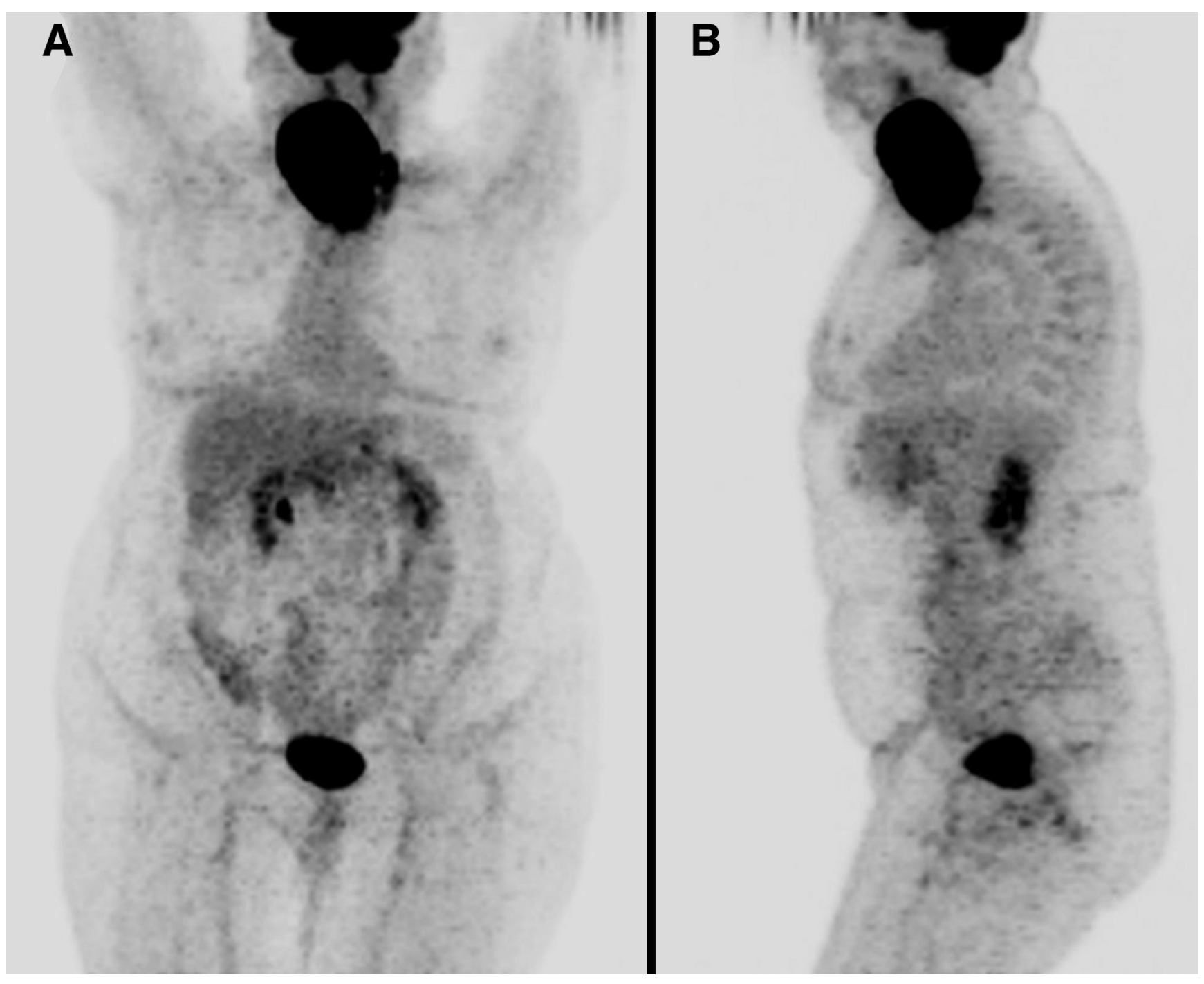

Figure 1. A 67-year-old woman with no prior history of benign thyroid disease presented with a two month history of fevers, night sweats, and rapidly enlarging neck mass. Biopsy of the right thyroid lobe revealed a diffuse large B-cell lymphoma (DLBCL). A staging 18F-fluoro-2-deoxy-D-glucose (18F-FDG) positron emission tomography/computed tomography (PET/CT) (Discovery-ST, GE Healthcare, WI, USA) was performed and maximum intensity projection (MIP) images, (A) anterior and (B) left lateral, showed a large intensely 18F-FDG avid mass in the right neck with no distant metastases. 

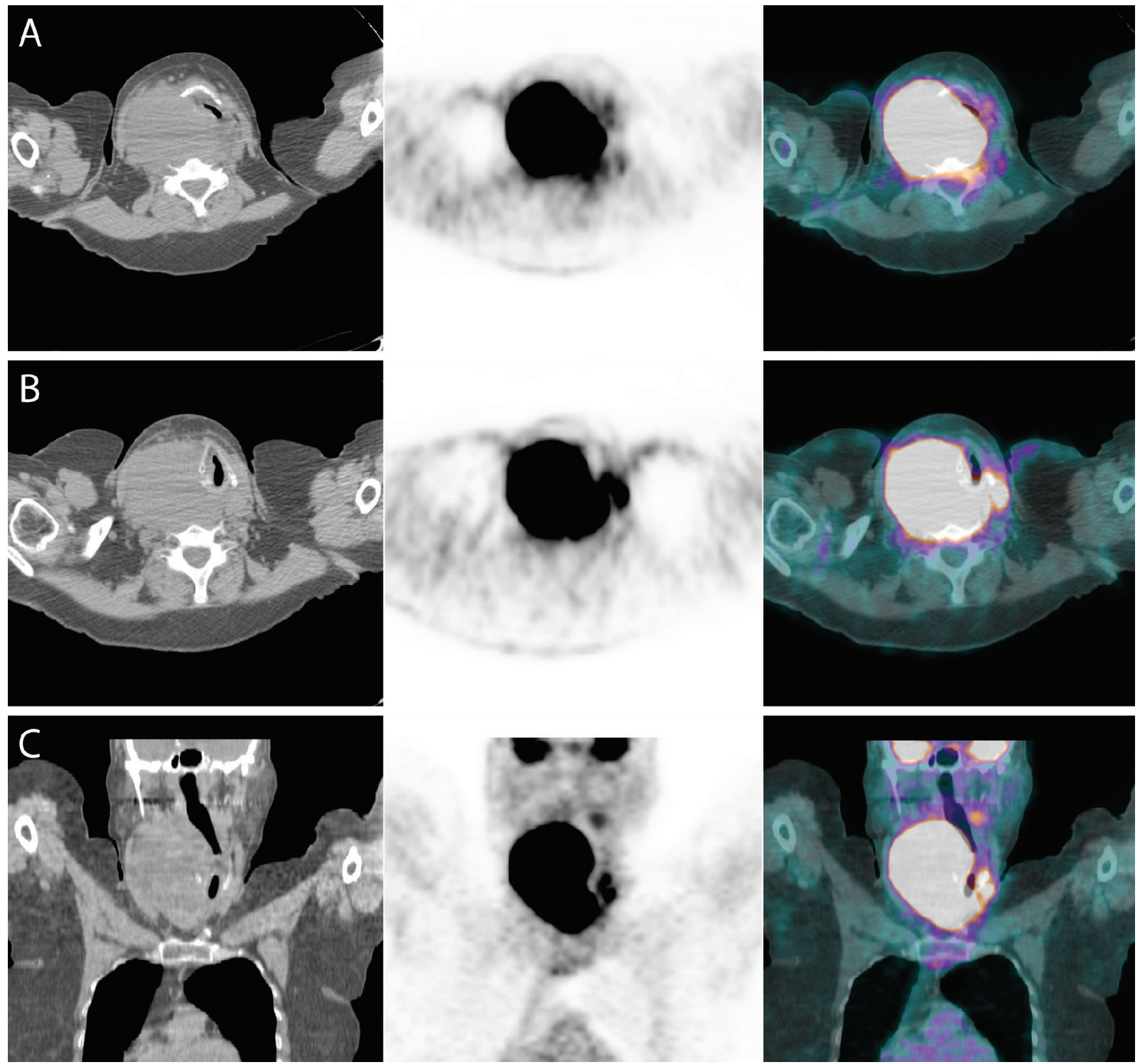

Figure 2. $(A, B)$ Transaxial and $(C)$ coronal views of the neck with $C T$ (left), PET (middle), and PET/CT fusion (right) images show right thyroid DLBCL, measuring $13 \times 9 \mathrm{~cm}$ with maximum standardized uptake value $\left(S \cup V_{\max }\right) 54$, compressing the trachea to a narrow slit left of the midline. 


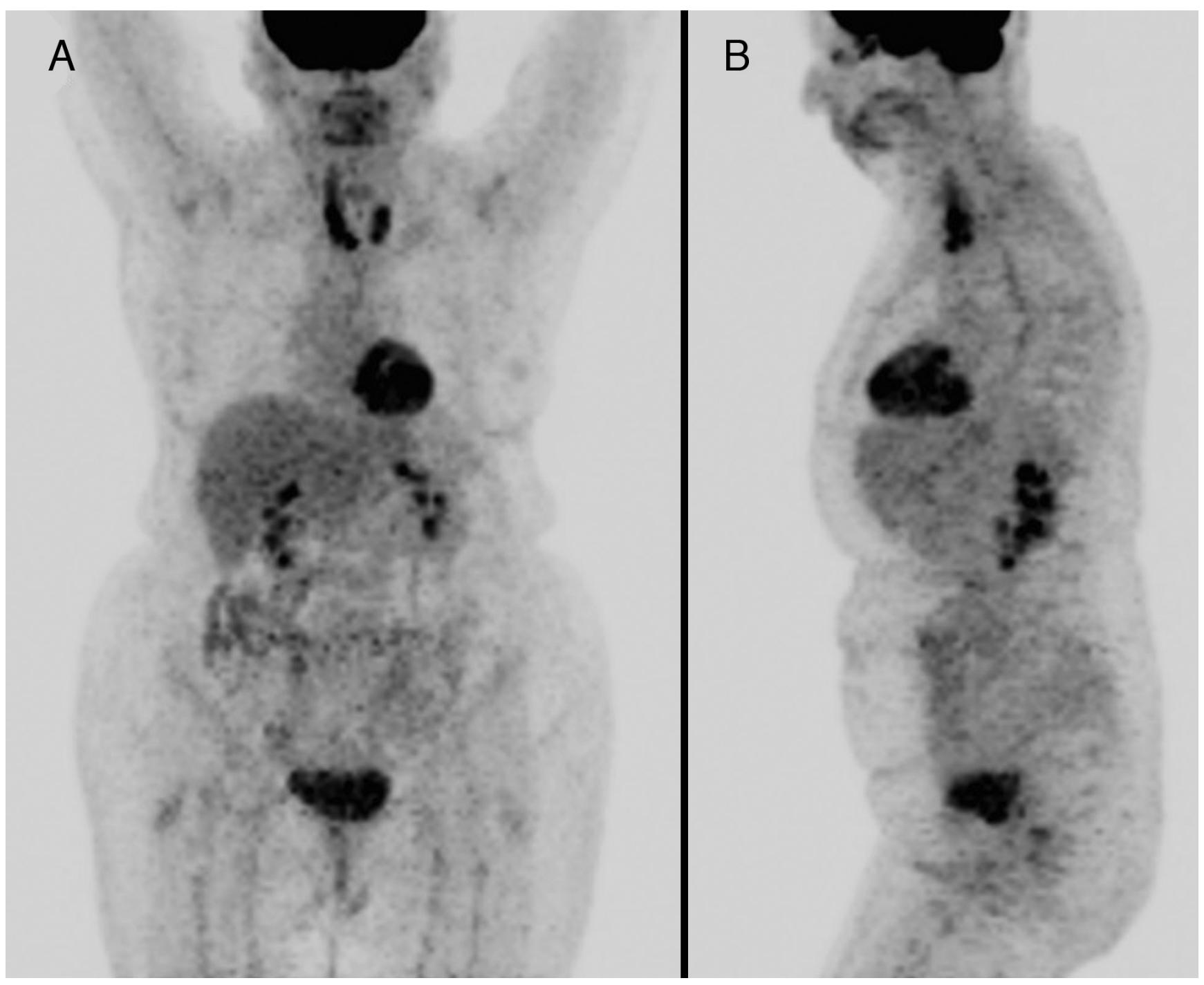

Figure 3. The patient was treated with 3 cycles of $\mathrm{CHOP}$ chemotherapy (cyclophosphamide, doxorubicin, vincristine, prednisone) followed by external beam radiation therapy. The first follow-up PET/CT was performed 3 months after the end of radiation therapy and MIP views, (A) anterior and (B) left lateral, show a dramatic reduction in the size of right thyroid DLBCL and resolution of tracheal compression with persistently intense ${ }^{18 F-F D G ~ u p t a k e}$ in both thyroid lobes with SUV $\max 8.9$ on the right. These findings were interpreted as partial response to therapy, however since the patient was asymptomatic, a conservative management approach was taken. 

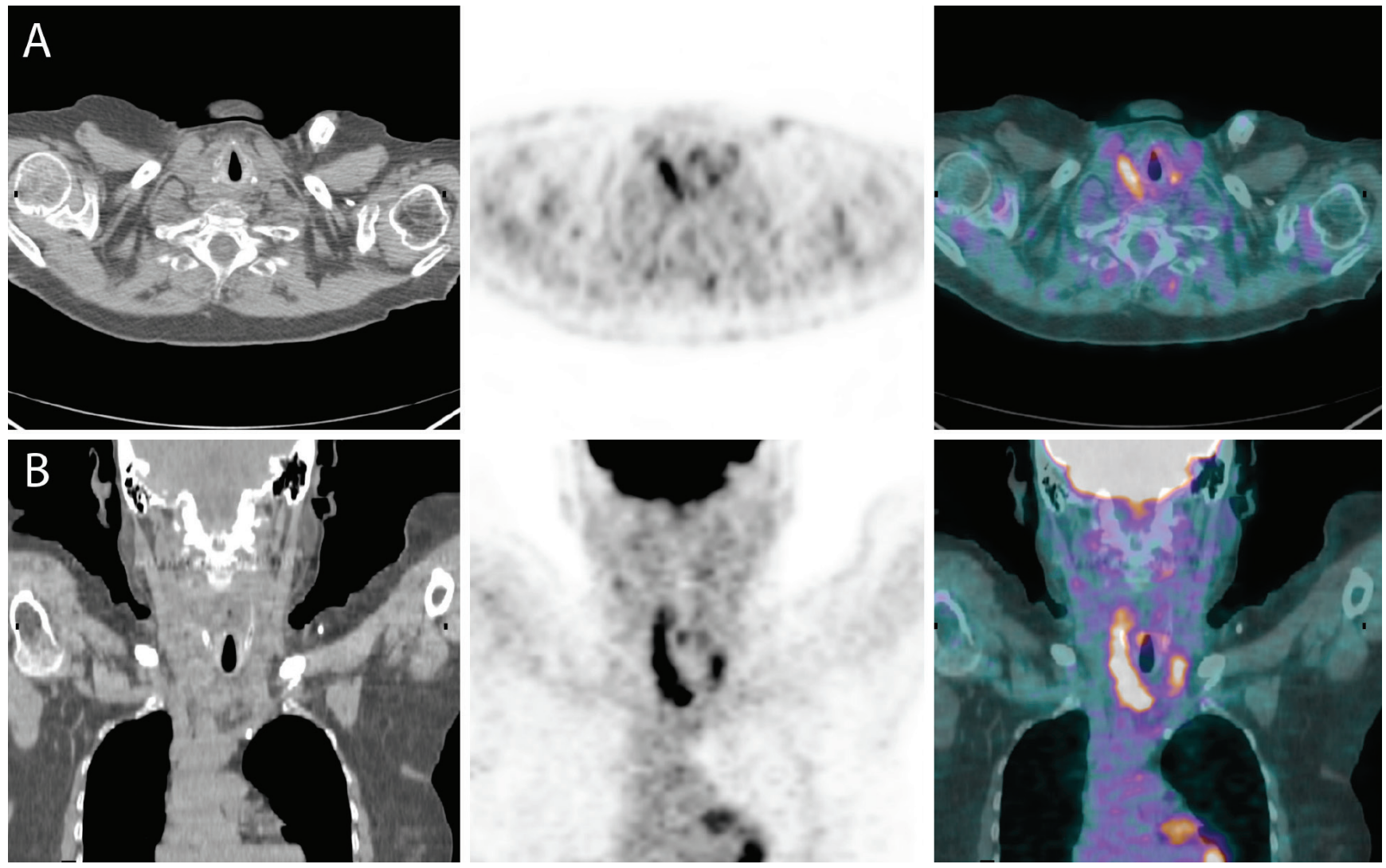

Figure 4. (A) Transaxial and (B) coronal views of the post therapy PET/CT showing apparent partial response to therapy. 


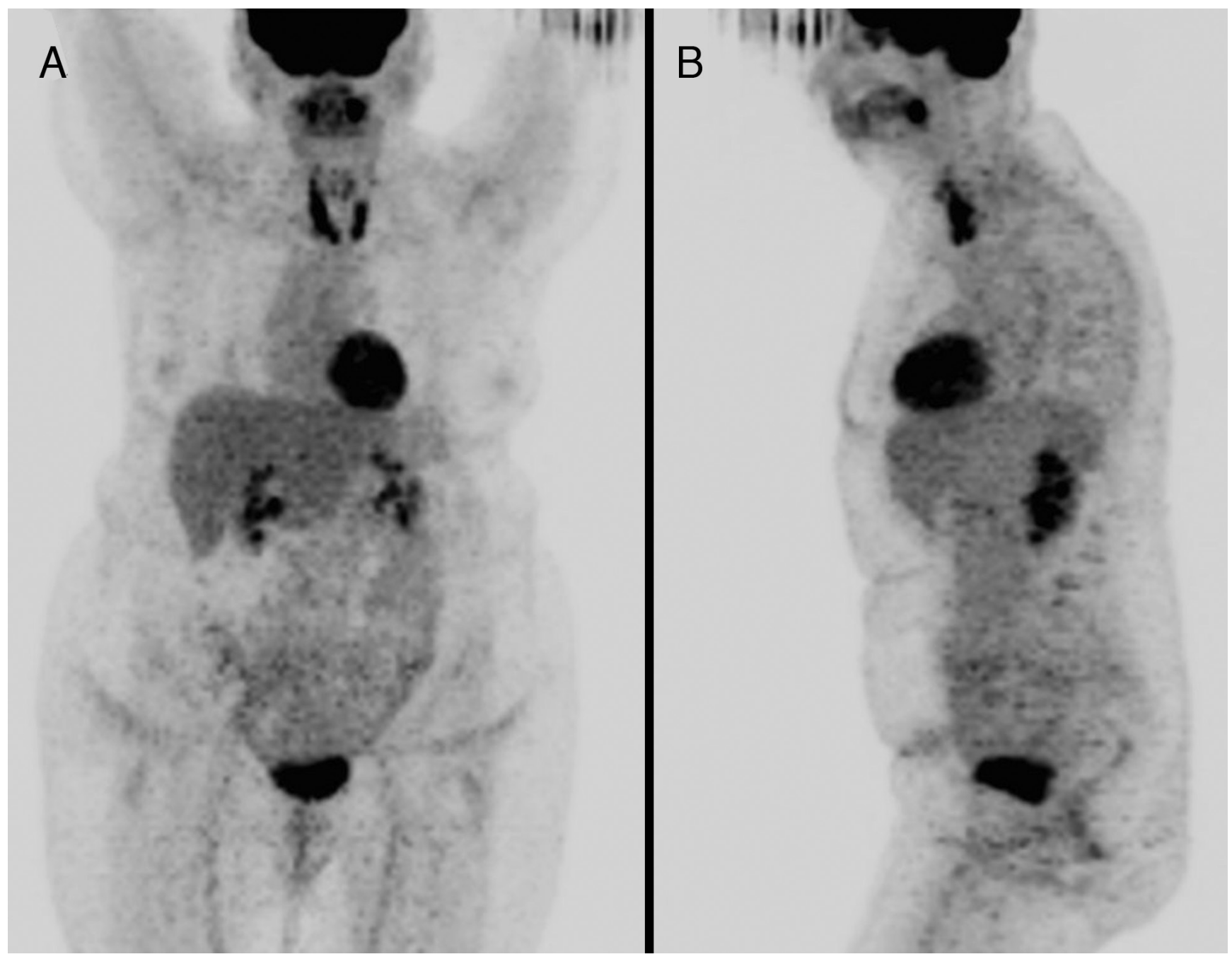

Figure 5. A second follow-up PET/CT was performed one year later. SUV $V_{\max }$ of right thyroid lobe was 10.2, unchanged according to PET Response Criteria in Solid Tumors (PERCIST 1.0). The pattern of 18F-FDG uptake and distribution in the thyroid gland were also unchanged. Biopsy of both thyroid lobes revealed thyroiditis with no evidence of residual lymphoma. A third follow-up PET/CT was performed 2 years later and SUV $\mathrm{max}_{\text {in }}$ the right thyroid lobe was 9.5 (unchanged according to PERCIST) with stable pattern of 18F-FDG uptake and distribution, consistent with remission. Primary thyroid lymphoma makes up $1-5 \%$ of thyroid malignancies and less than $2 \%$ of extranodal lymphomas (1). It is more common in women, and patients present in the seventh decade of life with rapidly enlarging neck mass $(1,2,3,4)$. The use of 18 F-FDG PET/CT to stage primary thyroid lymphoma and evaluate response to therapy has been previously reported in the literature $(5,6)$. Recent studies have raised concern about high rate of false positives on PET/ CT performed following therapy for thyroid lymphoma, although these have been attributed to Hashimoto's thyroiditis $(7,8,9,10,11,12)$. External beam radiation therapy can produce both inflammatory and proliferative changes in the thyroid gland with increases in macrophage populations $(9,10)$. Studies have shown that 18 F-FDG uptake is increased in head and neck soft tissues affected by such inflammatory and proliferative processes and lasts several months after the completion of radiation therapy $(11,12)$. The present case is an example of a long-term post-treatment thyroiditis, which remained intensely 18 F-FDG avid but stable on several follow-up PET/CTs spanning three years, which to our knowledge has not been previously reported in the literature. 


\section{Ethics}

Informed Consent: All subjects in the study gave written informed consent or the institutional review board waived the need to obtain informed consent.

Peer-review: Externally peer-reviewed.

\section{Authorship Contributions}

Surgical and Medical Practices: W.M., A.C., S.P., Concept: W.M., Design: W.M., Data Collection or Processing: W.M., A.C., S.P., Analysis or Interpretation: W.M., A.C., S.P., Literature Search: W.M., A.C., S.P., Writing: W.M.

Conflict of Interest: No conflict of interest was declared by the authors.

Financial Disclosure: The authors declared that this study received no financial support.

\section{References}

1. Mack LA, Pasieka JL. An evidence-based approach to the treatment of thyroid lymphoma. World J Surg 2007:31:978-986.

2. Graff-Baker A, Roman SA, Thomas DC, Udelsman R, Sosa JA. Prognosis of primary thyroid lymphoma: demographic, clinical and pathologic predictors of survival in 1408 cases. Surgery 2009:146:1105-1115.

3. Graff-Baker A, Sosa JA, Roman SA. Primary thyroid lymphoma: a review of recent developments in diagnosis and histology-driven treatment. Curr Opin Oncol 2010;22:17-22.
4. Onal C, Li YX, Miller RC, Poortmans P, Constantinou N, Weber DC, Atasoy BM, Igdem S, Ozsahin M, Ozyar E. Treatment results and prognostic factors in primary thyroid lymphoma patients: a rare cancer network study. Ann Oncol 2011;22:156-164.

5. Lin EC. FDG PET/CT for assessing therapy response in primary thyroid lymphoma. Clin Nucl Med 2007;32:152-153.

6. Basu S, Li G, Bural G, Alavi A. Fluorodeoxyglucose positron emission tomography (FDG-PET) and PET/Computed tomography imaging characteristics of thyroid lymphoma and their potential clinical utility. Acta Radiol 2009;50:201-204.

7. Nakada K, Kamijo K, Fujimoto N, Sakuma I, Sakurai M. Is FDG PET valuable in monitoring early therapy response in primary thyroid lymphoma? J Nucl Med 2010;51:1611.

8. Kurata S, Ishibashi M, Hiromatsu Y, Kaida H, Miyake I, Uchida M, Hayabuchi N. Diffuse and diffuse-plus-focal uptake in the thyroid gland identified by using FDG-PET: prevalence of thyroid cancer and Hashimoto's thyroiditis. Ann Nucl Med 2007;21:325-330.

9. Hunt JL. Radiation induced thyroid diseases. Pathology Case Reviews 2009;14:224-230

10. Kubota R, Yamada S, Kubota K, Ishiwata K, Tamahashi N, Ido T. Intratumoral distribution of fluorine-18-fluorodeoxyglucose in vivo: high accumulation in macrophages and granulation tissues studied by microautoradiography. J Nucl Med 1992;33:1972-1980.

11. Yao M, Smith R, Graham MM, Hoffman HT, Tan H, Funk GF, Graham SM, Chang K, Dornfeld KJ, Menda Y, Buatti JM. The role of FDG PET in management of neck metastasis from head-and-neck cancer after definitive radiation treatment. Int J Rad Onc 2005;63:991-999.

12. Andrade RS, Heron DE, Degirmenci $B$, Filho PA, Branstetter $B F$, Seethala RR, Ferris RL, Avril N. Posttreatment assessment of response using FDG-PET/CT for patients treated with definitive radiation therapy for head and neck cancers. Int J Rad Onc 2006;65:13151322. 